\title{
Uptake of Pb and Cd by Plant Species: A Review
}

\author{
Elvis Wireko Boampong \\ Department of Environmental and Safety \\ University of Mines and Technology, UMaT \\ Tarkwa, Ghana
}

\begin{abstract}
The use of plants to extract heavy metals from contaminated soil is termed phytoextraction. In recent times, phytoextraction has gained traction as a method for the remediation of spoil soil due to its eco-friendliness and cost-effectiveness. This review study shows how several plant species like Inula viscosa $L$. artin, Euohorbia dendroides L, Salix Viminalis, Eucalyptus rostrate, Linnum utitatissimum L., Bryopyllum Pinnatum, Cistus salvifolius L, Helichrysium italicum, etc. can be used for the uptake of Lead $(\mathrm{Pb})$ and/or Cadmium (Cd) from contaminated soil. The review demonstrates that the uptake of these heavy metals from soil using selective plant species is effective and efficient.
\end{abstract}

Keywords:- Phytoremediation, Phytoextraction, Plant, Heavy Metals, Lead $(P d)$ and Cadmium $(C d)$.

\section{INTRODUCTION}

Heavy metal represents metal of relatively high density or high relative atomic weight. Heavy metal includes but not limited to Copper, Zinc, Cadmium, Lead, Nickel and Cobalt. Although these metals are naturally present in the earth crust, their concentration in soil and water mostly ranges from less than 1000ppm to a few ppb. Metalliferous soils are an exception as they naturally harbor extremely high concentrations of certain heavy metals $[7 ; 16]$. Anthropogenic activities such as mining, energy production, smelting, electroplating, sludge dumping, melting operations and agriculture have influenced greatly the concentration of heavy metals in areas beyond the critical-concentration $[8,17,21]$. Several technologies and interventions have been developed for treating metal contaminated soil. These technologies include isolation and containment, pyrometallurgical separation and in-situ stabilization by chemical treatment. Although these technologies are efficient, they are generally costly, labor-intensive and in some cases result in significant secondary damages or disturbance of the soil. In recent times, the use of plant (phytoremediation) in soil remediation has gained massive traction as it is an environmentally friendly and costeffective approach [10,21].

Phytoremediation refers to the use of plants to remove, transfer, stabilize and/or destroy contaminants in the soil or groundwater [21]. Phytoremediation strategies are phytofiltration, phytostabilization, phytoextraction, phytovolatilisation and phytodegradration [3,4,7]. Among these strategies, phytoextraction has been the commonly used technique [18]. Phytoextraction is the best approach to remove the contamination primarily from the soil and isolate it, without destroying the soil structure and fertility of the plant. According to [15], plant species such as Salvinia natain, Vallisneira Spiralis and Cabomba aquatica have the potential to uptake heavy metals from spoil land. Sebera Aciminate, Thlaspic Caerulescene, Arbidoposis thaliana, Typha Latifolia and Phragmtic austrials are also plant species capable of accumulating heavy metals in their tissues [7]. Plants that has a plant to soil ratio (bioaccumulation factor) and shoot to metal ratio (transfer factor) greater than 1 are termed hyperaccumulators [21]. Hyperaccumulators are capable of accumulating at least $1000 \mathrm{mg} / \mathrm{Kg}$ of $\mathrm{Cd}$, $1000 \mathrm{mg} / \mathrm{Kg}$ of $\mathrm{As}, \mathrm{Cu}, \mathrm{Pb}, \mathrm{Ni}, \mathrm{Co}, \mathrm{Se}, \mathrm{Cr}$ or $10000 \mathrm{mg} / \mathrm{Kg}$ of $\mathrm{Mn}$ or $\mathrm{Zn}[14,18]$.

[1] study showed a high Lead contamination of soils in most part of Tema, Ghana and [2] study also found high levels of $\mathrm{Cd}$ in several soils in Ghana. Remediating these $\mathrm{Pb}$ and $\mathrm{Cd}$ contaminated soils by plant will require the use of selective plant species.

The current review is about literature survey on the phytoextraction of Lead $(\mathrm{Pb})$ and/or Cadmium $(\mathrm{Cd})$ using selective plant species.

\section{REV IEW ON PHYTOEXTRACTION}

\section{$>$ Linnum utitatissimum L.}

Seeds of Linnum utitatissimum L. were sterilized and germinated in a pot with a diameter of $28 \mathrm{~cm}$ and depth of $30 \mathrm{~cm}$ filled with clay soil. The study employed four groups of identical pots. One group as the control, one with 10, 20, and $40 \mathrm{mg} / \mathrm{kg}$ of $\mathrm{CdCl}_{2}$ and the other group with $\mathrm{Pb}_{2}\left(\mathrm{CH}_{3} \mathrm{OO}\right)_{2}$ of 150,500 and $700 \mathrm{mg} / \mathrm{kg}$ respectively. Fertilizers were applied carefully to the various pot. The concentration of $\mathrm{Pb}$ and $\mathrm{Cd}$ in the soil samples was analyzed using AAS.

$\mathrm{Cd}$ concentration in the plant roots was higher than those in the aboveground parts of the plant with $77.4 \%$ in the soil sample treated with $40 \mathrm{mg} / \mathrm{kg}$ soil $\mathrm{Cd}$. The $\mathrm{Cd}$ concentrations in the parts of the plant were in the order of root $>$ shoot $>$ capsule $>$ seed. The highest $\mathrm{Pb}$ concentration in the plant was $55 \%$ in the soil sample treated with $700 \mathrm{mg} / \mathrm{kg}$ soil $\mathrm{Pb}$. The $\mathrm{Pb}$ concentration was in the order of capsule $>$ shoot $>$ root $>$ seed. Bioaccumulation factor $(\mathrm{BF})$ and transfer factor (TF) were greater than 1 for $\mathrm{Pb}$ but less than 1 for $\mathrm{Cd}$. The $\mathrm{TF}$ for $\mathrm{Pb}$ treatment was greater than 1 for the shoot and capsule but less than 1 for the seed and in the order of capsule $>$ shoot $>$ seed. The uptake potential of the heavy metals from the soil was $68.6 \%$ for $\mathrm{Pb}$ and $49 \%$ for $\mathrm{Cd}$. The highest uptake of $\mathrm{Cd}$ was recorded in the root while that of $\mathrm{Pb}$ was recorded in the capsule. The study showed that 
Linnum utitatissimum $L$. is a hyperaccumulator of $\mathrm{Pb}$ and an excluder for Cd. [12].

\section{$>$ Salix Viminalis}

The phytoextraction potential of Salix Viminalis on Cd and $\mathrm{Pb}$ was determined on two different sites, one calcareous and the other acidic. The study on the first site lasted for 5 years while the latter lasted for 2years.

In the first year, the uptake of heavy metals by the plant species was negligible but significant in the following year(s). The uptake of the heavy metals under study increased upon the addition of chelate agent Fe. The metal uptake at the acidic soil was twice higher than at the calcareous soil when uptake after two years was compared. The total uptake was $170 \mathrm{~g} /$ ha for $\mathrm{Cd}$ from the calcareous soil for the five-year study period and $47 \mathrm{~g} / \mathrm{ha}$ of $\mathrm{Cd}$ at the acidic soil after the two-year study period. Salix Viminalis performed better on the acidic soil as compared to the calcareous soil mainly because of the higher biomass production and higher metal concentration in the shoot. The leaves accumulated a higher amount of $\mathrm{Cd}$ than the stem. The concentration of the heavy metals decreased in the shoot over time. The study concluded that Salix Viminalis could have the potential for stabilization of contaminated soil. [11].

\section{$>$ Ricenus communic cv. Guarary}

$\mathrm{Pd}, \mathrm{Cd}$ and other heavy metals were the control of this experiment. The plant species were grown in pots filled with Hoagland and Amon's nutrients. In this experiment, six different $\mathrm{Pb}$ concentration $(0,6,12,24,48$ and $96 \mathrm{mg} / \mathrm{kg})$ in the form $\mathrm{Pb}\left(\mathrm{No}_{3}\right)_{2}$ and $\mathrm{Cd}$ concentration $(0,1,2,4,8$ and $16 \mathrm{mg} / \mathrm{kg}$ ) in the form of $\mathrm{Cd}\left(\mathrm{No}_{3}\right)_{2}$ were added to soil samples in two separate pots for 3days: the first pot was for $\mathrm{Cd}$ and the other for $\mathrm{Pb}$. The plant was harvested after 30days and prepared for analysis. The heavy metal concentrations were determined using flame-AAS. TF, BF and Effective Concentration (EC25 AND EC50) for growth in response to $\mathrm{Cd}$ were calculated. EC25 and EC50 exposures are the values at which the dry weight/matter reduces by $25 \%$ and $50 \%$ relative to the highest value for the dry matter (100\%).

$\mathrm{Pb}$ had no effect on the dry matter of the plant but an increase in the concentration of $\mathrm{Cd}$ in the hydrophone system led to a reduction of root and shoot dry matter. At the lowest concentration of $\mathrm{Cd}(1 \mathrm{mg} / \mathrm{kg})$, there was a reduction of $44 \%$ and $55 \%$ in the root and shoot dry matter respectively. For the highest $\mathrm{Cd}$ concentration, reduction in the dry matter of the root and shoot was $97 \%$ in both root and shoot. EC25 and EC50 values were 0.5 and $1.1 \mathrm{mg} / \mathrm{L}$ for the root, 0.4 and $0.9 \mathrm{mg} / \mathrm{L}$ for the shoot respectively.

For this study, TF was less than 1 for $\mathrm{Cd}$ and $\mathrm{Pb}$ while $\mathrm{BF}$ was greater than 1 for $\mathrm{Cd}$ and less than 1 for $\mathrm{Pb}$ except for the concentration of $24 \mathrm{mg} / \mathrm{L}$ of $\mathrm{Pb}$. The $\mathrm{Pb}$ and $\mathrm{Cd}$ concentrations found in the shoots were both smaller than $1000 \mathrm{mg} / \mathrm{kg}$. Cd was more toxic to the plant while the plant showed a significant tolerance for $\mathrm{Pb}$. Ricenus communic cv. Guarary is more efficient for the phytoextraction of $\mathrm{Pb}$. [5].
> Helichrysium italicum, Arundo dinax L., Cistus salvifolius L., Poa annua L., Holosclaenus australis L. Rchb, Inula viscosa L. artin and Euohorbia dendroides $L$.

The phytoextraction potential of the above plant species on an abandoned mine was studied. Inductively Coupled Plasma - Optical Emission Spectroscopy (ICP-OES) was used in determining $\mathrm{Cd}$ concentration while $\mathrm{Pb}$ concentration was determined using Flame-ASS equipped with background correction. The mean concentration of $\mathrm{Cd}$ and $\mathrm{Pd}$ was $1800 \mathrm{mg} / \mathrm{kg}$ and $56 \mathrm{mg} / \mathrm{kg}$ in the tailings. In the sediments, the mean $\mathrm{Pb}$ and $\mathrm{Cd}$ concentrations were $2900 \mathrm{mg} / \mathrm{kg}$ and $100 \mathrm{mg} / \mathrm{kg}$ and $200 \mathrm{mg} / \mathrm{kg}$ and $80 \mathrm{mg} / \mathrm{kg}$ in the pasture soil.

The highest metal accumulation in the lower parts (root and rhizome) was seen in Poa annua L. and Holosclaenus australis L. Rchb while that of the upper parts (leaves and stems) were seen in the remaining species. The $\mathrm{Pb}$ concentrations accumulated by the plants ranged from $3-$ $1300 \mathrm{mg} / \mathrm{kg}$ with the highest recorded in the root of Euohorbia dendroides $L$. In the aerial parts, the highest $\mathrm{Pb}$ concentration was $950 \mathrm{mg} / \mathrm{kg}$ found in Helichrysium italicum. Inula viscosa $L$. artin and Euohorbia dendroides $L$ showed high $\mathrm{Pb}$ content in their leaves $(700$ and $650 \mathrm{mg} / \mathrm{kg}$ respectively). Cd concentration in the plants ranged from 0.5 to $170 \mathrm{mg} / \mathrm{kg}$ with the highest concentration recorded in the root of Poa annua L. The highest $\mathrm{Cd}$ concentration in the aerial parts was $44 \mathrm{mg} / \mathrm{kg}$ found in Inula viscosa L. artin. The species Inula viscosa L. artin, Euohorbia dendroides L. and Poa annua $L$ showed relatively high metal uptake in the aboveground biomass with mean averages of 420, 240 and $80 \mathrm{mg} / \mathrm{kg}$ of $\mathrm{Pb}$ and 28,7 and $19 \mathrm{mg} / \mathrm{kg}$ of $\mathrm{Cd}$ respectively. Arundo dinax $L$ also demonstrated a significant potential for the phytoextraction of $\mathrm{Cd}$ and $\mathrm{Pb}$. Cistus salvifolius $L$ and Helichrysium italicum demonstrated behaviors more suitable for phytostabilization. [3].

\section{Ipomoea aquatic and Spinacia oleracea}

In this study, synthetic soil was induced with $66 \mathrm{ppm}$ of $\mathrm{Pb}\left(\mathrm{No}_{3}\right)_{2}$ and 30ppm of $\mathrm{Cd}\left(\mathrm{No}_{3}\right)_{2}$ that resulted in $\mathrm{Cd}$ and $\mathrm{Pd}$ concentrations of $14.4 \mathrm{mg} / \mathrm{kg}$ and $36 \mathrm{mg} / \mathrm{kg}$ in the soil.

Seeds of the plants were planted in an unpolluted soil and transplanted in the synthetic coil after 2 months of growth. After 35days following the transplant, the concentration of the metals was analyzed using AAS. The phytoextraction potential of the plants was expressed as percentages. $\mathrm{TF}$ for $\mathrm{Pb}$ and $\mathrm{Cd}$ was estimated.

The growth of the plants was inversely proportional to the concentration of the heavy metals. There were shorter lengths of roots of the plants exposed to the heavy metals compared to those harvested from the unpolluted soil. The shorter length of the roots could be attributed to the higher concentration of $\mathrm{Cd}$. For the $\mathrm{Pb}$ concentration (66ppm), TF was 0.49 for Ipomoea aquatic and 0.17 for Spinacia oleracea. For the Cd concentration (30ppm), TF was 0.48 for Ipomoea aquatic and 0.38 for Spinacia oleracea. The accumulation of $\mathrm{Cd}$ was greater than $\mathrm{Pb}$ for both species. Ipomoea aquatic had the highest efficiency for the removal of $\mathrm{Pb}$ and $\mathrm{Cd}$ with $27.79 \%$ of $\mathrm{Pb}$ and $29 \%$ of $\mathrm{Cd}$. The 
potential for phytoextraction was higher in Ipomoea aquatic than Spinacia oleracea. [20].

\section{- Acacia saligna, Eucalyptus rostrate and Conocarpus erectu}

This study was to determine the ability of the above species to uptake $\mathrm{Pb}$ and $\mathrm{Cd}$ in plastic pots containing soil mixed with fine powders of $\mathrm{CdCl}_{2}$ and $\mathrm{PdCl}_{2}$. The soil in the plastic pots had $\mathrm{Pb}$ levels of $00,250,500$ and $1000 \mathrm{mg} / \mathrm{kg}$ and Cd levels of $0,250,500$ and $1000 \mathrm{mg} / \mathrm{kg}$ soil. Three months old seedlings of the species were transplanted in the plastic pots with sand, peat moss and a $\mathrm{pH}$ of 7.2. There was the addition of water-soluble fertilizers. After harvest, the concentration of $\mathrm{Pb}$ and $\mathrm{Cd}$ in the plant tissues were analyzed using ICP-AES (Inductively Coupled Plasma - Atomic Emission Spectroscopy). Peroxidase and Catalase activities were also studied.

Catalase activity increased at $\mathrm{Pb} 1$ and $\mathrm{Pb} 2$ but decreased at $\mathrm{Pb} 3$ for all plant species while it increased at $\mathrm{Cd} 1$ and $\mathrm{Cd} 2$ for only Acacia saligna and Eucalyptus rostrate but decreased at $\mathrm{Cd} 3$ for all species. Peroxidase activity increased in $\mathrm{Pb} 1$ and $\mathrm{Pb} 2$ for all species and also increased in $\mathrm{Cd} 1$ and $\mathrm{Cd} 2$ but decreased in $\mathrm{Cd} 3$ for all species. The highest level of Cd treatment $(1000 \mathrm{mg} / \mathrm{kg})$ caused a reduction of the dry shoot weight by $39 \%, 45.8 \%$ and $49.3 \%$ while the highest $\mathrm{Pb}$ treatment resulted in a decrease of the shoot dry weight by $25.8 \%, 27.4 \%$ and $35.8 \%$ in Acacia saligna, Eucalyptus rostrate and Conocarpus erectu respectively. The lowest $\mathrm{Pb}$ treatment resulted in an increase in the shoot dry weight by $15.9 \%, 13.6 \%$ and $8.7 \%$ in Acacia saligna, Eucalyptus rostrate and Conocarpus erectu respectively. The plants showed a low tolerance for $\mathrm{Cd}$ concentrations. Unlike Conocarpus erectu, the $\mathrm{Pb}$ and $\mathrm{Cd}$ accumulated in Acacia saligna and Eucalyptus rostrate were higher in the roots than in the shoots. The highest uptake of $\mathrm{Pb}$ and $\mathrm{Cd}$ content was by Acacia saligna $(625$ and $62 \mathrm{mg} / \mathrm{kg}$ in the root and 258 ad $32 \mathrm{mg} / \mathrm{kg}$ in the shoot). The $\mathrm{Pb}$ and $\mathrm{Cd}$ content were 552 and $52 \mathrm{mg} / \mathrm{kg}$ in the root and 316 and $43 \mathrm{mg} / \mathrm{kg}$ in the shoot of Eucalyptus rostrate. For Conocarpus erectu, the $\mathrm{Pb}$ and $\mathrm{Cd}$ content was 165 and $35 \mathrm{mg} / \mathrm{kg}$ in the root and 285 and $56 \mathrm{mg} / \mathrm{kg}$ in the shoot respectively. TF for both $\mathrm{Pb}$ and $\mathrm{Cd}$ was less than 1 for Acacia saligna and Eucalyptus rostrate but greater than 1 for Conocarpus erectu. Although large amounts of metal content were accumulated in the roots, only lower levers were translocated into the shoot in the case of Acacia saligna and Eucalyptus rostrate. The highest metal uptake was by Acacia saligna. Cd had a high inhibition effect than $\mathrm{Pb}$ on the weight of the roots and shoots of the plant species. The dry weight of shoots and roots reduces for all plant species as the concentration of the heavy metals increases. There was a significant tolerance to heavy metal concentrations by Acacia saligna than the other plant species. Conocarpus erectu showed the least tolerance to increasing concentration of the heavy metals. All three plant species demonstrated significant potential for the uptake of heavy metals. [19].

\section{> Delonox regra, Leucaena leucocephala and Thespesra populneoicles}

The removal of $\mathrm{Cd}$ and $\mathrm{Pb}$ by the above plant species were studied using a pot experiment. The seedlings were grown on the soil induced with Lead Acetate and Cadmium Chloride of concentrations 25, 50, 75, 100 and 125ppm. The experiment employed completely randomized design (C.R.D) and the data were analyzed using analysis of variance and Duncan's multiple ranges of tests. Tolerance index (T.I), Diclofenac (DFC) and phytotoxicity were estimated as percentages.

For all three species, a reduction in growth was observed. The aerial germination was not significantly affected by the induced $\mathrm{Pb}$ and $\mathrm{Cd}$ toxicity. Thespesra populneoicles depicted a $50 \%$ reduction in germination at 1000ppm for Cd toxicity while Delonox regra and Leucaena leucocephala showed a reduction lesser than $50 \%$ at the same $\mathrm{Cd}$ toxicity. Leucaena leucocephala germination exceeded $90 \%$ in the Lead Acetate and $70-80 \%$ in Cadmium Chloride. There were higher percentages of DFC in Delonox regra than the remaining plant species, thus Delonox regra seeds are more susceptible to these heavy metals. The high levels of $\mathrm{Pb}$ and $\mathrm{Cd}$ resulted in a decrease of the root length of all the investigated plant species with the highest reduction observed in the $125 \mathrm{ppm}$ of $\mathrm{Cd}$ and $\mathrm{Pb}$. The average T.I of $\mathrm{Pb}$ and $\mathrm{Cd}$ were 69.1 and 53.38 for Delonox regra, 53.99 and 16.6 for Leucaena leucocephala and 59.32 and 38.89 for Thespesra populneoicles respectively. In general, $\mathrm{Cd}$ exhibited a toxic potential to the plants than $\mathrm{Pb}$. The higher the concentration of the metals, the slower the germination of the seedlings. The growth of Leucaena leucocephala was least affected by $\mathrm{Cd}$ and $\mathrm{Pd}$. Tolerance for $\mathrm{Cd}$ and $\mathrm{Pb}$ was highest in Delonox regra but moderate in the remaining plant species. Delonox regra demonstrated a higher phytoextraction potential than the other investigated plant species. [13].

\section{> Panicum virdatum $L$.}

The efficiency of Panicum virdatum $L$. to uptake $\mathrm{Cd}$ and $\mathrm{Pd}$ in 3 groups of 5 replica pots with five different concentrations of $\mathrm{Pb}(195.4,400,700,1000$ and $1204.6 \mu \mathrm{g} / \mathrm{g})$ and $\mathrm{Cd}(9.45,30,60,90$ and $110.46 \mu \mathrm{g} / \mathrm{g})$ and five different $\mathrm{pH}$ (3, 4.1, 5.8, 7.5 and 8.6) was studied. The seeds were germinated, transferred to a plastic container with quartz sand and then transplanted in the pots. The pots were all supplied with adequate nutrient solution and water. $50 \mathrm{mg} / \mathrm{kg}$ solution of $\mathrm{CdCl}_{2}$ and $\mathrm{Pb}\left(\mathrm{No}_{3}\right)_{2}$ were added to each pot every 2days while adjusting the $\mathrm{pH}$. Superoxide dismutase (SOD) and Peroxidase (POD) activities were also determined.

SOD and POD and Malondialdehyde (MDA) activities were affected. The interaction of $\mathrm{Cd}$ and $\mathrm{Pb}$ in the soil had an antagonistic effect on the $\mathrm{BF}$ of $\mathrm{Cd}$ while the interaction of $\mathrm{pH}$ with $\mathrm{Cd}$ or $\mathrm{Pb}$ showed a synergistic effect on the $\mathrm{BF}$ of $\mathrm{Cd}$. The $\mathrm{Cd}$ and $\mathrm{Pb}$ concentrations were higher in the root than in the shoot. The accumulated $\mathrm{Cd}$ concentrations in the root and shoot range from $33.86-487.61 \mu \mathrm{g} / \mathrm{g}$ and $6.63-$ $59.43 \mu \mathrm{g} / \mathrm{g}$ respectively. $\mathrm{Pb}$ concentration accumulated in the root and shoot ranged from $64.87-2205.52 \mu \mathrm{g} / \mathrm{g}$ and $10.76-$ $104.27 \mu \mathrm{g} / \mathrm{g}$ respectively. $\mathrm{BF}$ for $\mathrm{Cd}$ was greater than 1 but 
less than 1 for $\mathrm{Pb}$ while $\mathrm{TF}$ for both $\mathrm{Cd}$ and $\mathrm{Pb}$ was less than 1. The study concluded that Panicum virdatum $L$. could grow in the soil with a Cd concentration of $48.68 \mu \mathrm{g} / \mathrm{g}, \mathrm{Pb}$ concentration of $56.75 \mu \mathrm{g} / \mathrm{g}$ and a p.H of 5.34. Panicum virdatum $L$. was more efficient in the removal of $\mathrm{Cd}$ than $\mathrm{Pb}$. [9].

\section{$>$ Bryopyllum Pinnatum}

In this study, the species was planted on a polluted soil and nurtured for 20 weeks. The plant and soil were collected and analyzed every four weeks. The metal concentrations were analyzed using the wet digestion method. The total concentration of $\mathrm{Cd}$ and $\mathrm{Pb}$ were determined using Atomic
Absorption Spectrometer (AAS) equipped with attractive background correction. Cd concentration extracted by the plant species was $3.12 \pm 1.03 \mathrm{mg} / \mathrm{kg}$ while $\mathrm{Pb}$ was $399.90 \pm$ $4.32 \mathrm{mg} / \mathrm{kg}$. The uptake of heavy metals increases as the period of exposure to the heavy metals increases except for the fifth month. The bioaccumulation of the heavy metals was in the order of $\mathrm{Pb}>\mathrm{Cd}$. Therefore, Bryopyllum Pinnatum has higher phytoextraction potential for $\mathrm{Pb}$ than $\mathrm{Cd}$ in this very experiment. [6].

Table 1 shows the plants species and their respective $\mathrm{TF}$ and $\mathrm{BF}$ on $\mathrm{Pb}$ and $\mathrm{Cd}$.

\begin{tabular}{|l|l|l|l|l|}
\hline \multirow{2}{*}{ Plant Species } & \multicolumn{1}{|l|}{} & $\boldsymbol{B F}$ & $\boldsymbol{C d}$ \\
\cline { 2 - 5 } & $\boldsymbol{P b}$ & $\boldsymbol{C d}$ & $\boldsymbol{P d}$ & $<1$ \\
\hline Linnum utitatissimum L & $>1$ & $<1$ & $>1$ & $>1$ \\
\hline Ricenus communic cv Guarary & $<1$ & $<1$ & $<1$ & - \\
\hline Ipomoea aquatic & $<1$ & $<1$ & - & - \\
\hline Spinacia oleracea & $<1$ & $<1$ & - & - \\
\hline Acacia saligna & $<1$ & $<1$ & - & - \\
\hline Eucalyptus rostrate & $<1$ & $>1$ & - & - \\
\hline Conocarpus erectu & $>1$ & $<1$ & $<1$ & $>1$ \\
\hline Panicum virdatum L & $<1$ & & \\
\hline
\end{tabular}

Table 1:- TF and BF of plant species

\section{CONCLUSION}

The uptake of $\mathrm{Pb}$ and/or $\mathrm{Cd}$ potential of Delonox regra, Leucaena leucocephala, Thespesra populneoicles, Acacia saligna, Eucalyptus rostrate, Conocarpus erectu, Ipomoea aquatic, Spinacia oleracea, Bryopyllum Pinnatum, Panicum virdatum L., Helichrysium italicum, Arundo dinax L., Cistus salvifolius L., Poa аппиа L., Holosclaenus australis L. Rchb, Inula viscosa L. artin, Euohorbia dendroides L., Ricenus communic cv. Guarary, Salix Viminalis, and Linnum utitatissimum $L$. have been effectively discussed. Most of these species demonstrated significant uptake of $\mathrm{Pb}$ and/or $\mathrm{Cd}$, signifying their effectiveness for the phytoremediation of these heavy metals. Linnum utitatissimum $L$ was a hyperaccumulator for $\mathrm{Pb}$ and an excluder for Cd. Cistus salvifolius L., Salix Viminalis and Helichrysium italicum showed behaviors suitable for phytostabilization. In most scenarios, increasing concentration of heavy metals showed a toxic effect on the growth of the plant species. High concentrations of $\mathrm{Cd}$ showed an inhibiting effect on Ricenus communic $c v$ Guarary and Conocarpus erectu.

The majority of the studies conducted were in the laboratory settings (pot experiment), field experiments will be required to understand the phytoextraction abilities of the plant species fully. Phytoremediation has proven effective in many studies, and hence, it should be given more attention, especially in Ghana.

\section{ACKNOWLEDGMENT}

The author would like to acknowledge Mr. Stephen Wireko, colleagues in the Department of Environmental and Safety Engineering and the Department of Minerals Engineering for their assistance and provision of necessary resources.

\section{REFERENCES}

[1]. Aboh, I.J.K., Sampson, M.A., Nyaab, L.A.K., Caravanos, J., Ofosu, F.G. and Kuranchie-Mensah, H., 2013. Assessing levels of lead contamination in soil and predicting pediatric blood lead levels in Tema, Ghana. Journal of Health and Pollution, 3(5), pp.7-12.

[2]. Agyarko, K., Darteh, E. and Berlinger, B., 2010. Metal levels in some refuse dump soils and plants in Ghana. Plant, Soil and Environment, 56(5), pp.244251.

[3]. Barbafieri, M., Dadea, C., Tassi, E., Bretzel, F. and Fanfani, L., (2011). Uptake of heavy metals by native species growing in a mining area in Sardinia, Italy: discovering native flora for phytoremediation. International Journal of Phytoremediation, 13(10), pp.985-997.

[4]. Chandra, R. and Kumar, V., (2017). Phytoextraction of heavy metals by potential native plants and their microscopic observation of root growing on stabilised distillery sludge as a prospective tool for in situ phytoremediation of industrial waste. Environmental Science and Pollution Research, 24(3), pp.2605-2619. 
[5]. de Souza Costa, E.T., Guilherme, L.R.G., de Melo, É.E.C., Ribeiro, B.T., Euzelina dos Santos, B.I., da Costa Severiano, E., Faquin, V. and Hale, B.A., (2012). Assessing the tolerance of castor bean to $\mathrm{Cd}$ and $\mathrm{Pb}$ for phytoremediation purposes. Biological trace element research, 145(1), pp.93-100.

[6]. Ekwumemgbo, P.A., Eddy, N.O. and Omoniyi, I.K., (2013). Decontamination of heavy metals in polluted soil by phytoremediation using bryophyllum pinnatum. In E3S Web of Conferences (Vol. 1, p. 13004). EDP Sciences.

[7]. Gardea-Torresdey, J.L., Peralta-Videa, J.R., De La Rosa, G. and Parsons, J.G., (2005). Phytoremediation of heavy metals and study of the metal coordination by X-ray absorption spectroscopy. Coordination chemistry reviews, 249(17-18), pp.1797-1810.

[8]. Ghosh, M. and Singh, S.P., (2005). A review on phytoremediation of heavy metals and utilization of it's by products. Asian J Energy Environ, 6(4), p.18.

[9]. Guo, Z., Gao, Y., Cao, X., Jiang, W., Liu, X., Liu, Q., Chen, Z., Zhou, W., Cui, J. and Wang, Q., (2019). Phytoremediation of $\mathrm{Cd}$ and $\mathrm{Pb}$ interactive polluted soils by switchgrass (Panicum virgatum L.). International Journal of Phytoremediation, 21(14), pp.1486-1496.

[10]. Ha, N.T.H., Sakakibara, M., Sano, S. and Nhuan, M.T., (2011). Uptake of metals and metalloids by plants growing in a lead-zinc mine area, Northern Vietnam. Journal of Hazardous Materials, 186(2-3), pp.1384-1391.

[11]. Hammer, D., Kayser, A. and Keller, C., (2003). Phytoextraction of $\mathrm{Cd}$ and $\mathrm{Zn}$ with Salix viminalis in field trials. Soil Use and Management, 19(3), pp.187192.

[12]. Hosman, M.E., El-Feky, S.S., Elshahawy, M.I. and Shaker, E.M., (2017). Mechanism of phytoremediation potential of flax (Linum usitatissimum L.) to $\mathrm{Pb}, \mathrm{Cd}$ and Zn. Asian J Plant Sci Res, 7(4), pp.30-40.

[13]. Ismail, S., Khan, F.A.R.I.H.A. and Iqbal, M.Z., (2013). Phytoremediation: assessing tolerance of tree species against heavy metal $(\mathrm{Pb}$ and $\mathrm{Cd})$ toxicity. Pakistan Journal of Botany, 45(6), pp.2181-2186.

[14]. Mahmood, T., (2010). Phytoextraction of heavy metals-the process and scope for remediation of contaminated soils. Soil Environ, 29(2), pp.91-109.

[15]. Mânzatu, C., Nagy, B., Ceccarini, A., Iannelli, R., Giannarelli, S. and Majdik, C., (2015). Laboratory tests for the phytoextraction of heavy metals from polluted harbor sediments using aquatic plants. Marine pollution bulletin, 101(2), pp.605-611.

[16]. Mattina, M.I., Lannucci-Berger, W., Musante, C. and White, J.C., (2003). Concurrent plant uptake of heavy metals and persistent organic pollutants from soil. Environmental pollution, 124(3), pp.375-378.

[17]. Nouri, J., Khorasani, N., Lorestani, B., Karami, M., Hassani, A.H. and Yousefi, N., (2009). Accumulation of heavy metals in soil and uptake by plant species with phytoremediation potential. Environmental Earth Sciences, 59(2), pp.315-323.

[18]. Pajević, S., Borišev, M., Nikolić, N., Arsenov, D.D., Orlović, S. and Župunski, M., (2016). Phytoextraction of heavy metals by fast-growing trees: a review. In Phytoremediation (pp. 29-64). Springer, Cham.

[19]. Qados, A.M.S.A., (2015). Phytoremediation of $\mathrm{Pb}$ and $\mathrm{Cd}$ by native tree species grown in the kingdom of Saudi Arabia. Intl Res J Agri Sci Soil Sci, 3(1), pp.2234.

[20]. Saad, F.N.M., Lim, F.J., Izhar, T.N.T. and Odli, Z.S.M., (2020) April. Evaluation of phytoremediation in removing $\mathrm{Pb}, \mathrm{Cd}$ and $\mathrm{Zn}$ from contaminated soil using Ipomoea Aquatica and Spinacia Oleracea. In IOP Conference Series: Earth and Environmental Science (Vol. 476, No. 1, p. 012142). IOP Publishing.

[21]. Yashim, Z.I., Kehinde Israel, O. and Hannatu, M. (2014). A study of the uptake of heavy metals by plants near metal-scrap dumpsite in Zaria, Nigeria. Journal of Applied chemistry, 2014, pp.1-5. 